\title{
Reversibility of myocardial hypertrophy 8 years after adrenal adenoma excision and drugs and alcohol addiction withdrawal
}

\author{
Gian Piero Carboni
}

Department of Nuclear Cardiology, Università Campus Bio-Medico, Rome, Italy

\section{Correspondence to} Professor Gian Piero Carboni, g.carboni@unicampus.it

\section{DESCRIPTION}

In November 2005, a 37-year-old patient presented to us with a systolic blood pressure (BP) $>180 \mathrm{Hg}$ and a diastolic BP $>110 \mathrm{Hg}$ and a history of dramatic hypertensive crises despite adherence to treatment with several antihypertensive drugs. $\mathrm{He}$ worked as a waiter in a nightclub where he was exposed to tiredness and fatigue while working nights. He sniffed at least $2 \mathrm{~g}$ of cocaine, smoked around $2 \mathrm{~g}$ of hashish and drank more than $500 \mathrm{ml}$ of brandy nearly every night. This habit lasted for 5 years. Despite the presence of a positive direct relationship between cocaine, hashish, alcohol abuse and hypertension, ${ }^{12}$ the patient underwent a clinical workup to rule out other causes of secondary hypertension. The findings of hypokalaemia and increased values of aldosteronaemia and aldosteronuria suggested a diagnosis of primary aldosteronism. Echocardiography found a severe left ventricular hypertrophy (LVH). Abdominal CT identified a mass on the left adrenal gland (figure 1). The gland was excised by laparoscopic surgery (figure 2), and histological examination of the mass indicated adrenal adenoma. ${ }^{3}$ After surgery, the patient began a new job as a clerk with a normal working day and gradually discontinued drug and alcohol abuse. A daily treatment with $240 \mathrm{mg}$ of verapamil and $50 \mathrm{mg}$ of losartan maintained normal BP values. After an 8-year follow-up, echocardiography

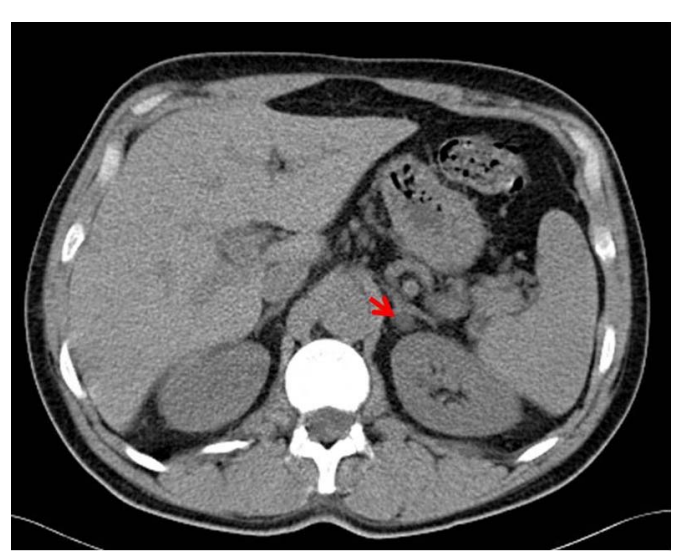

Figure 1 Abdominal CT-axial view: adrenal adenoma (red arrow).

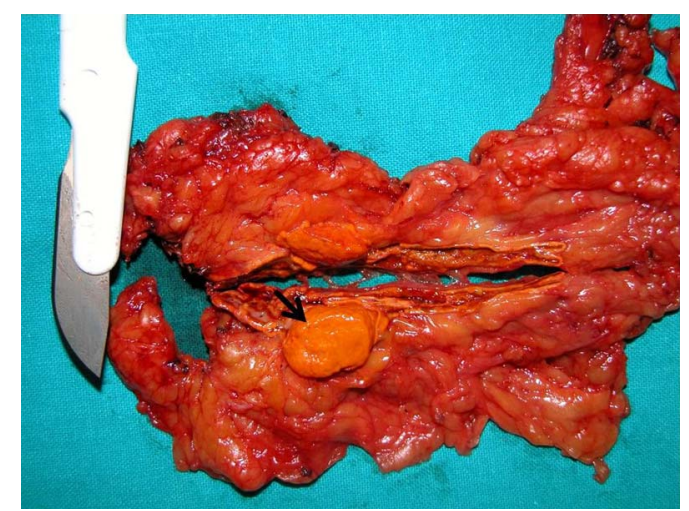

Figure 2 Excised adrenal gland and the adenoma (black arrow).

showed a reduction of the $\mathrm{LV}$ mass and $\mathrm{LVH}^{4}$ (figure 3). These results indicate a favourable prognosis for cardiovascular events in this patient.
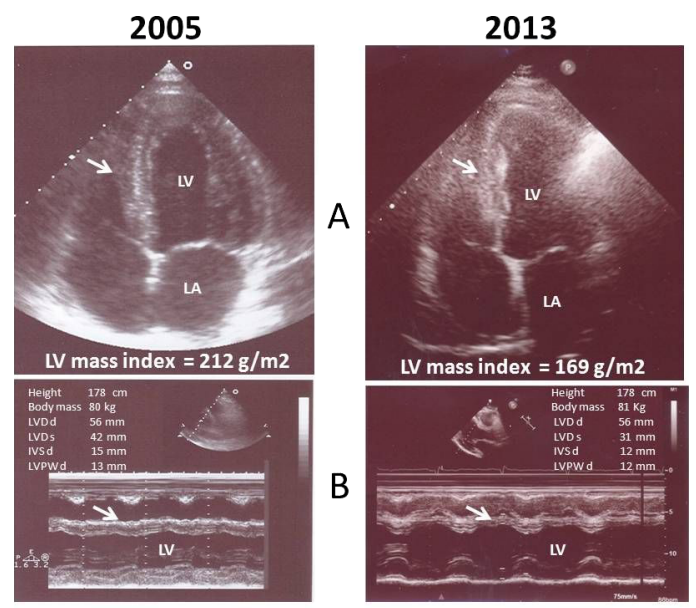

Figure 3 Concentric left ventricular hypertrophy (LVH) (2005). LVH reduction (2013). Septal wall (white arrows). LV, left ventricle; LA, left atrium; LVDd, LV dimension in diastole; LVDs, LV dimension in systole; IVSd, interventricular septum thickness in diastole; LPWd, LV posterior wall thickness in diastole. 


\section{Learning points}

- The findings of hypokalaemia, elevated values of aldosteronaemia and aldosteronuria indicate screening for primary aldosteronism.

- There are different forms of primary aldosteronism:

- Aldosterone-producing adenomas.

- Bilateral adrenal hyperplasia.

- Familial hyperaldosteronism type I. The genetic defect is characterised by the presence of a hybrid or chimeric gene on chromosome $8 q$.

- Familial hyperaldosteronism type II is characterised by autosomal dominant inheritance and the hypersecretion of aldosterone due to adreno-cortical hyperplasia or an aldosterone-producing adenoma.

- Aldosterone-producing adreno-cortical carcinomas.

- Ectopic aldosterone-producing tumours.

- CT is a non-invasive, feasible and safe technique for the diagnosis of aldosterone-producing tumours. The excision of adrenal adenomas may cause myocardial hypertrophy reversal.
Acknowledgements The author would like to thank the colleagues of the University Campus Bio-Medico di Roma, who performed the patient's imaging and provided the laparoscopy surgery. The author would also like to thank Dr Alessandro Boccanelli who kindly revised the echocardiograms.

Contributors GPC followed-up this patient for 8 years, organised all the diagnostic procedures and suggested the therapy. He wrote the paper and revised the images.

Competing interests None.

Patient consent Obtained.

Provenance and peer review Not commissioned; externally peer reviewed.

\section{REFERENCES}

1 Akkina SK, Ricardo AC, Patel A, et al. Illicit drug use, hypertension, and chronic kidney disease in the US adult population. Trans/ Res 2012;160:391-8.

2 Sesso HD, Cook NR, Buring JE, et al. Alcohol consumption and the risk of hypertension in women and men. Hypertension 2008;51:1080-7.

3 Herd A, Harman R, Taylor E. Surgical outcomes following laparoscopic adrenalectomy for treatment of Conn's syndrome (primary hyperaldosteronism) between 1999 and 2006. N Z Med J 2010;123:50-6.

4 Okin PM, Devereux RB, Jern S, et al. Relation of echocardiographic left ventricular mass and hypertrophy to persistent electrocardiographic left ventricular hypertrophy in hypertensive patients: the LIFE Study. Am J Hypertens 2001;14(8 Pt 1):775-82.

Copyright 2013 BMJ Publishing Group. All rights reserved. For permission to reuse any of this content visit http://group.bmj.com/group/rights-licensing/permissions.

BMJ Case Report Fellows may re-use this article for personal use and teaching without any further permission.

Become a Fellow of BMJ Case Reports today and you can:

- Submit as many cases as you like

- Enjoy fast sympathetic peer review and rapid publication of accepted articles

- Access all the published articles

- Re-use any of the published material for personal use and teaching without further permission

For information on Institutional Fellowships contact consortiasales@bmjgroup.com

Visit casereports.bmj.com for more articles like this and to become a Fellow 